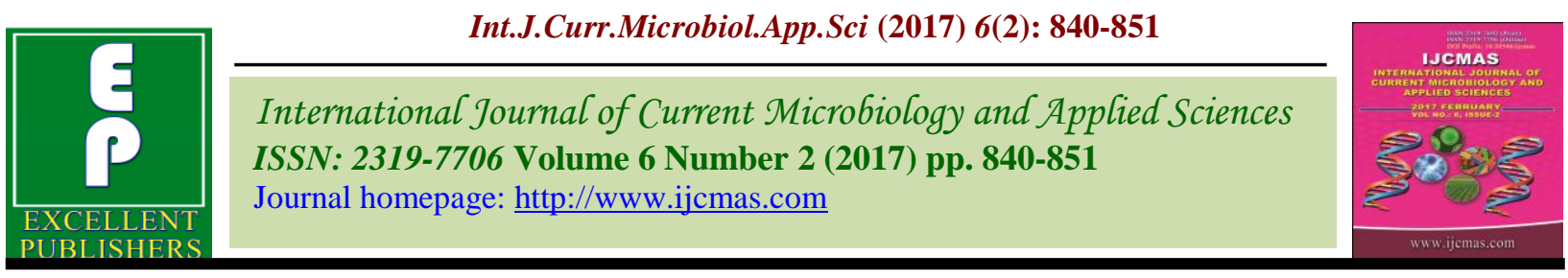

Original Research Article

http://dx.doi.org/10.20546/ijcmas.2017.602.094

\title{
Biochemical Identification of Protease Producing Bacterial Isolates from Food Industries by Vitek 2 Compact System
}

\author{
I.S. Sony* and V.P. Potty \\ Department of Microbiology, Cashew Export promotion Council of India (CEPCI), \\ Mundakkal, Kollam, Kerala, India \\ *Corresponding author:
}

\section{A B S T R A C T}

Keywords

Protease, Biomerieux

VITEK 2 system,

Staphylococcus

sciuri,

Achromobacter

xylosoxidans.

Article Info

Accepted:

18 January 2017

Available Online:

10 February 2017
The objective of the present study was to identify protease producing bacteria isolated from food processing industries. Isolation of the organism was performed by serial dilution agar plate technique and initial screening of protease production was done using gelatine agar plates by flooded the plates with mercuric chloride solution $\left(\mathrm{HgCl}_{2}-15 \mathrm{~g}\right.$ and $20 \mathrm{ml}$ of $6.0 \mathrm{~N} \mathrm{HCl}$ made up to $100 \mathrm{ml}$ with distilled water). A total of 5 isolates were selected based on zone diameter in gelatine clear zone method and named as TKMFT8, TKMFT22, TKMFT25, TKMFT39 and TKMFT53. Initial identification of the selected isolates was carried out using cultural characterization, microscopic observation and Biomerieux VITEK 2 system identification based on biochemical reactions and identified as Staphylococcus sciuri (TKMFT8, TKMFT22, TKMFT25, and TKMFT39) and Achromobacter xylosoxidans (TKMFT53). Protease producing bacterial isolates can be used for the degradation proteinaceous waste material from food manufacturing units leading to recycling of food industry waste.

\section{Introduction}

Proteases are representative of group of enzymes which catalyze the breakdown of polypeptide chains into smaller polypeptides or amino acids (Deng et al., 2010). Bacteria secrete proteases to hydrolyse the peptide bonds in proteins into their constituent monomers (amino acids). Bacterial and fungal proteases are important to the global carbon and nitrogen cycles in protein recycling which tends to be regulated by nutritional signals in these organisms. The overall impact of nutritional regulation of protease activity among the thousands of species present in soil can be observed at the overall microbial community level because proteins are broken down in response to nitrogen, carbon or sulfur limitation. Proteases were first grouped in 1993 into 84 families according to their evolutionary relationship, and classified under four catalytic types: cysteine, serine, aspartic, and metallo proteases. The glutamic-acid and threonine proteases were not described until 2004 and 1995 respectively. The mechanism used for the breakdown of peptide bond involves making an amino acid residue that has the cysteine and threonine (proteases) or a water molecule (aspartic acid, metallo- and acid proteases) nucleophilic hence, it can 
attack the peptide carboxyl group. One way to make a nucleophile is by a catalytic triad, where a histidine residue is used to activate serine, cysteine, or threonine as a nucleophile. Proteases are involved cleavage of long protein chains into shorter fragments by cleaving the peptide bonds that link amino acid residues. Some detach the terminal amino acids from the protein chain (exopeptidases, such as carboxypeptidase A, aminopeptidases), others attack internal peptide bonds of a protein (endopeptidases, such as pepsin, trypsin, papain, elastase).

Proteases represent the class of enzymes which occupy a pivotal position with respect to their physiological roles as well as their commercial applications. Proteases perform both synthetic as well as degradative functions. Since proteases are physiologically necessary for living organisms, they occur ubiquitously in a wide diversity of sources such as microorganisms, plants and animals. Microorganisms are an attractive source of proteases due to the limited space required for their cultivation and their susceptibility to genetic manipulation. Proteases are categorised into exo- and endopeptidases based on their action at or away from the termini, respectively. Depending on the nature of the functional group at the active site, proteases are also classified as serine proteases, aspartic proteases, cysteine proteases, and metalloproteases. Proteases play a significant role in many physiological and pathophysiological processes. Based on their classification, four different types of catalytic mechanisms are operative. Proteases find tremendous applications in the food and dairy industries. Alkaline proteases hold a great potential for application in the detergent and leather industries because of the increasing trend to develop environmentally friendly technologies. There is a renaissance of interest in the application of proteolytic enzymes as targets for therapeutic agents development. Cloning and sequencing of protease genes from several bacteria, fungi, and viruses have been performed with the prime aims of (i) overproduction of the protease enzyme by gene amplification, (ii) delineation of the role of the enzyme in pathogenecity, and (iii) alteration in the properties of enzyme to suit its commercial application. Protein engineering techniques have been exploited to get proteases which show unique specificity and/or enhanced stability at high $\mathrm{pH}$ or temperature or in the presence of detergents and to understand the structure-function relationships of protease enzyme. Protein sequences of acidic, alkaline, and neutral proteases from various origins have been studied with the aim of studying their evolutionary relationships. Despite the extensive research on several aspects of proteases, there is a paucity of knowledge about the roles that govern the diverse specificity of these enzymes (Rao et al., 1998).

The major bacterial genera which contribute to proteases include Aeromonas, Alcaligenes, Arthrobacter, Bacillus, Halomonas, Pseudomonas and Serratia (Shafee et al., 2005; Rao et al., 1998), Brevibacterium linens (Rattray, 1995), Alteromonas sp.(Yeo et al., 1995), Hyphomonas jannaschiana VP 3 (Shi et al., 1997), Microbacterium sp. (Gessesse and Gashe, 1997) Pimelobacter sp.z-483 (Oyama et al.,1997) Salinivibrio sp. Strain AF-2004 (Heidari et al., 2007) Streptomyces isolate EGS-5 (Ahmad, 2011) Streptomyces microflavus (Rifaat et al., 2006) Streptomyces rimosus (Yang and Wang ,1999) Thermoactinomyce ssp. (Lee et al.,1996) Thermoactino mycesthalpophilus THM1 (Anderson et al.,1997), Lactobacillus helveticus (Valasaki et al., 2008).

VITEK 2 is an automated microbial identification system that provides highly reproducible and accurate results as shown in 
multiple independent studies. With its colorimetric reagent cards and associated hardware and software advances, the VITEK 2 offers a state-of-the-art technology platform for phenotypic identification methods. The GN identification card is based on established biochemical methods and newly developed substrates measuring carbon source utilization, enzymatic activities, and (Chang et al., 2002, Coenye et al., 2001, De Baere et al., 2001, Smith et al., 1991, Vandamme et al., 1999). The GP identification card is based on established biochemical techniques and newly developed substrates (Atlas, 1993, Barros et al., 2001, Collins and Lawson 2000, Collins et al., 2001, Poyart et al., 2002, Schlegel et al., 2000, Whiley et al., 1999).

In the present study, isolation of protease producing bacteria was carried out from soil and water samples collected from food industry surroundings. The protease producing ability was determined using gelatine clear zone method and biochemical identification was carried out by using Biomerieux VITEK 2 system.

\section{Materials and Methods}

\section{Isolation of protease producing bacterial isolates}

Soil and water samples were collected and stored in sterilized containers at $4^{\circ} \mathrm{C}$ until analysis. Soil samples were collected from different areas in Halwa manufacturing units such as close premises of such units, directly from the gluten landfill body by removing the surface soil and subsurface soil dug to a depth of about 1meter and from the edge of the landfill body. Water samples collected comprised of waste water from the food processing units. The collected samples were used to isolate protease producing microorganisms by serial dilution agar plate technique described by Sjodahl et al., (2002). An aliquot of $1 \mathrm{gram} / 1 \mathrm{ml}$ of soil and water sample was taken and it was added to $9 \mathrm{ml}$ of sterile distilled water and serially diluted up to $10^{-6}$ dilution. From each dilution $0.1 \mathrm{ml}$ was spread on nutrient agar plates and plates were incubated at $37^{\circ} \mathrm{C}$ for 48 hours.

\section{Screening of protease producing strains}

Screening of protease producing organism generally composed of growth of organism on the medium that composed of protein as a selective substrate and in the present study Gelatin was used as the substrate. A total of 87 dissimilar colonies from nutrient agar plates were selected and each isolate was given a reference number (TKMFT 01 to TKMFT 87) and each isolate was subjected to primary screening for the production of protease by plate assay using protease specific medium containing $(\mathrm{g} / \mathrm{l})$ glucose $1.0, \mathrm{~K}_{2} \mathrm{HPO}_{4}$ 2.0, Peptone 5.0, gelatin 15.0, and agar 15 . After $24 \mathrm{~h}$ incubation at $28^{\circ} \mathrm{C}$, the clear zone diameters were measured by flooded the plates with mercuric chloride solution $\left(\mathrm{HgCl}_{2}\right.$ $15 \mathrm{~g}$ and $20 \mathrm{ml}$ of $6.0 \mathrm{~N} \mathrm{HCl}$ made up to 100 $\mathrm{ml}$ with distilled water), this method was described as gelatine clear zone method (Galil, 1992). Based on the zone diameter, 5 isolates (TKMFT 8, TKMFT22, TKMFT25, TKMFT39 \& TKMFT53) were selected for further experimental studies.

\section{Qualitative test for protease}

Bacterial colonies appeared on agar plates were screened for evaluating their proteolytic potential by inoculating them in gelatin agar medium. Out of 87 isolates, 5 isolates were used in present study for thorough investigation as it exhibited most prominent zones of proteolysis around the colony. Protein hydrolysis was expressed as diameter of clear zone in millimetre $(\mathrm{mm})$. Based on the results obtained in the biochemical identification, 5 isolates were selected for quantitative test for protease activity 


\section{Identification of protease producing bacteria}

\section{Colony morphology}

The colony morphology of selected bacterial isolates was examined on nutrient agar plates. After the incubation, characterization of individual colonies was performed based on their shape, colour, appearance, size, transparency, pigmentation, form, margin and elevation (Aneja, 2003).

\section{Microscopic observation-Gram's staining}

The selected bacterial isolates were Gram stained in accordance with the standard procedure for Gram's staining described by Todar et al., (2005).

\section{Biochemical identification of Bacteria using Biomerieux Vitek 2 System}

The selected organisms were identified using VITEK 2 compact-Biomerieux, France automatic system in Cashew Export promotion Council of India (CEPCI), Kollam and the test method was A O A C OMA 2012.02. VITEK-2 system imparts an automated, computer based technique of species identifications, relies on advanced colorimetry technology, the measurement of light attenuation associated with each biochemical reactions in VITEK cards (Gramnegative fermenting and non-fermenting bacilli (GN), Gram-positive cocci and nonspore-forming bacilli (GP), yeasts and yeastlike organisms (YST), Gram-positive sporeforming bacilli (BCL)). The reagent cards have 64 wells and each well contain an individual test substrate. Substrates assess various metabolic activities such as alkalinisation, acidification, enzyme hydrolysis, and growth in the presence of inhibitory compounds. The VITEK-2 compact system combines several advantages like rapid identification, a simple methodology, a high level of automation and taxonomically updated databases.

\section{Results and Discussion}

\section{Isolation and screening of Protease producing bacteria}

Protease producing organisms were isolated from soil and waste water collected from the close premises of food processing industries using serial dilution agar plate technique (Rupali, 2015, Sjodahl et al., 2002, Tennalli et al., 2012, Sinha et al., 2013). The proteolysis ability of 87 bacterial isolates from soil and waste water samples were evaluated using Gelatine agar medium. A wide range of methods are available using Gelatin as substrate for detecting proteases (Grubb, 1994). Following inoculation and incubation of the Gelatin agar plates, organisms secreting protease enzyme exhibited a zone of proteolysis which was shown by a clear area around bacterial colonies. Among 87 isolated bacteria, 27 isolates were protease producer based on zone of hydrolysis and out of them 5 isolates (TKMFT 8, TKMFT22, TKMFT25, TKMFT39 and TKMFT53) were chosen for further studies based on the diameter of zone of hydrolysis as shown in Plate.2.

Sharma et al., (2015) reported that gelatine agar medium was best than skim milk agar medium for qualitative test for detecting protease production because zone of hydrolysis were obtained with more clarity in gelatine agar plates. These isolates were streaked on Nutrient agar plates as shown in Plate 4.3 and slants of these isolates were prepared on nutrient agar medium in screw capped tubes and maintained at $4^{\circ} \mathrm{C}$ for further experimental studies. Clear zone formation around bacterial colonies was considered as the evidence of production of protease. The results of bacterial isolates showing zone of inhibition (Diameter in $\mathrm{mm}$ ) are presented in table 1 . 
Screening of protease producing bacteria -

Primary screening on Gelatin agar medium

According to the results presented in Table.1 and Fig.1 the highest zone diameter on Gelatin Agar medium was obtained for TKMFT $8(26 \mathrm{~mm})$ followed by TKMFT22 (25mm) TKMFT39 (23mm), TKMFT25 $(20 \mathrm{~mm})$ and TKMFT53 (15mm). Five different bacterial isolates showed clear zone indicating enzyme production on gelatine agar plates were selected for secondary screening.

Identification of Protease producing bacterial isolates

Potent protease producers were biochemically identified using Biomerieux VITEK 2 system.

Table.1 Bacterial isolates showing zone of inhibition (Diameter in $\mathrm{mm}$ )

\begin{tabular}{|c|c|c|}
\hline SI No & $\begin{array}{c}\text { Bacterial } \\
\text { isolates }\end{array}$ & $\begin{array}{c}\text { Diameter of Zone } \\
\text { of hydrolysis(mm) }\end{array}$ \\
\hline 1 & TKMFT 8 & 26 \\
\hline 2 & TKMFT 22 & 25 \\
\hline 3 & TKMFT25 & 20 \\
\hline 4 & TKMFT 39 & 23 \\
\hline 5 & TKMFT 53 & 15 \\
\hline
\end{tabular}

Table.2 Colony morphology and microscopic observation of TKMFT8, TKMFT22, TKMFT25, TKMFT39 \& TKMFT53

\begin{tabular}{|c|c|c|c|c|c|c|c|c|}
\hline \multirow{2}{*}{$\begin{array}{l}\text { SI } \\
\text { No }\end{array}$} & \multirow[t]{2}{*}{$\begin{array}{l}\text { Bacterial } \\
\text { isolates }\end{array}$} & \multirow{2}{*}{$\begin{array}{c}\text { Result of Gram } \\
\text { staining }\end{array}$} & \multicolumn{6}{|c|}{ Colony characters on Nutrient agar } \\
\hline & & & $\mathbf{A}$ & $\mathbf{B}$ & $\mathbf{C}$ & $\mathbf{D}$ & $\mathbf{E}$ & $\mathbf{F}$ \\
\hline 1 & $\begin{array}{l}\text { TKMFT } 8, \\
22,25,39\end{array}$ & Gram positive cocci & Medium & Dark yellow & Circular & Entire & Flat & Rough \\
\hline 5 & TKMFT53 & Gram negative bacilli & Small & No & Circular & Entire & Flat & Smooth \\
\hline
\end{tabular}

A: Size; B: Pigmentation; C: Form; D: Margin; E: Elevation; F: Texture 
Table.3 Biochemical details of organisms identified using BIOMERIEUX VITEK/GP Cards

\begin{tabular}{|c|c|c|c|}
\hline \multirow[b]{2}{*}{ Well } & \multirow[b]{2}{*}{ Test } & \multirow[b]{2}{*}{ Mnemonic } & \multirow{2}{*}{$\begin{array}{c}\text { Result } \\
\text { TKMFT } 8,22,25,39 \\
\end{array}$} \\
\hline & & & \\
\hline 2 & D-AMYGDALIN & AMY & + \\
\hline 4 & $\begin{array}{l}\text { PHOSPHATIDYLINOSITOL } \\
\text { PHOSPHOLIPASE C }\end{array}$ & PIPLC & - \\
\hline 5 & D-XYLOSE & $\mathrm{dXYL}$ & - \\
\hline 8 & ARGININE DIHYDROLASE 1 & ADH1 & + \\
\hline 9 & BETA-GALACTOSIDASE & BGAL & - \\
\hline 11 & ALPHA-GLUCOSIDASE & AGLU & + \\
\hline 13 & Ala-Phe-Pro ARYLAMIDASE & APPA & - \\
\hline 14 & CYCLODEXTRIN & CDEX & - \\
\hline 15 & L-Aspartate ARYLAMIDASE & AspA & - \\
\hline 16 & BETA GALACTOPYRANOSIDASE & BGAR & - \\
\hline 17 & ALPHA-MANNOSIDASE & AMAN & - \\
\hline 19 & PHOSPHATASE & PHOS & + \\
\hline 20 & Leucine ARYLAMIDASE & LeuA & - \\
\hline 23 & L-Proline ARYLAMIDASE & ProA & - \\
\hline 24 & BETA GLUCURONIDASE & BGURr & - \\
\hline 25 & ALPHA-GALACTOSIDASE & AGAL & - \\
\hline 26 & L-Pyrrolidonyl-ARYLAMIDASE & PyrA & - \\
\hline 27 & BETA-GLUCURONIDASE & BGUR & + \\
\hline 28 & Alanine ARYLAMIDASE & AlaA & - \\
\hline 29 & Tyrosine ARYLAMIDASE & TyrA & - \\
\hline 30 & D-SORBITOL & dSOR & - \\
\hline 31 & UREASE & URE & - \\
\hline 32 & POLYMIXIN B RESISTANCE & POLYB & - \\
\hline 37 & D-GALACTOSE & dGAL & + \\
\hline 38 & D-RIBOSE & $\mathrm{dRIB}$ & + \\
\hline 39 & L-LACTATE alkalinisation & ILATk & + \\
\hline 42 & LACTOSE & LAC & - \\
\hline 44 & N-ACETYL-D-GLUCOSAMINE & NAG & + \\
\hline 45 & D-MALTOSE & dMAL & + \\
\hline 46 & BACITRACIN RESISTANCE & $\mathrm{BACl}$ & + \\
\hline 47 & NOVOBIOCIN RESISTANCE & $\mathrm{NOVO}$ & + \\
\hline 50 & GROWTH IN $6.5 \% \mathrm{NaCl}$ & NC6.5 & + \\
\hline 52 & D-MANNITOL & dMAN & + \\
\hline 53 & D-MANNOSE & dMNE & + \\
\hline 54 & METHYL-B-D-GLUCOPYRANOSIDE & MBdG & + \\
\hline 56 & PULLULAN & PUL & - \\
\hline 57 & D-FAFFINOSE & dRAF & - \\
\hline 58 & O/129 RESISTANCE (comp. vibrio.) & O129R & + \\
\hline 59 & SALICIN & SAL & + \\
\hline 60 & SACCHAROSE/SUCROSE & SAC & + \\
\hline 62 & D-TREHALOSE & dTRE & + \\
\hline 63 & ARGININE DIHYDROLASE 2 & $\mathrm{ADH} 2 \mathrm{~s}$ & - \\
\hline 64 & OPTOCHIN RESISTANCE & OPTO & + \\
\hline
\end{tabular}


Table.4 Biochemical details of organisms identified using BIOMERIEUX VITEK/GNCards

\begin{tabular}{|c|c|c|c|}
\hline Well & Test & Mnemonic & $\begin{array}{c}\text { Result } \\
\text { TKMFT } 53 \\
\end{array}$ \\
\hline 2 & Ala-Phe-Pro-ARYLAMIDASE & APPA & - \\
\hline 3 & ADONITOL & $\mathrm{ADO}$ & - \\
\hline 4 & ARYLAMIDASE & PyrA & - \\
\hline 5 & L-ARABITOL & IARL & - \\
\hline 7 & D-CELLOBIOSE & $\mathrm{dCEL}$ & - \\
\hline 9 & BETA-GALACTOSIDASE & BGAL & - \\
\hline 10 & H2S PRODUCTION & $\mathrm{H} 2 \mathrm{~S}$ & - \\
\hline 11 & BETA-N-ACETYL-GLUCOSAMINIDASE & BNAG & + \\
\hline 12 & Glutamyl Arylamidase Pna & AGLTp & - \\
\hline 13 & D-GLUCOSE & $\mathrm{dGLU}$ & + \\
\hline 14 & GAMMA-GLUTAMYL-TRANSFERASE & GGT & + \\
\hline 15 & FERMENTATION/GLUCOSE & OFF & - \\
\hline 17 & BETA-GLUCOSIDASE & BGLU & + \\
\hline 18 & D-MALTOSE & dMAL & - \\
\hline 19 & D-MANNITOL & dMAN & + \\
\hline 20 & D-MANNOSE & dMNE & - \\
\hline 21 & BETA-XYLOSIDASE & BXYL & + \\
\hline 22 & BETA-Alanine arylamidase pNA & BAlap & - \\
\hline 23 & L-Proline ARYLAMIDASE & ProA & - \\
\hline 26 & LIPASE & LIP & + \\
\hline 27 & PALATINOSE & PLE & - \\
\hline 29 & Tyrosine ARYLAMIDASE & TyrA & + \\
\hline 31 & UREASE & URE & - \\
\hline 32 & D-SORBITOL & dSOR & - \\
\hline 33 & SACCHAROSE/SUCROSE & SAC & + \\
\hline 34 & D-TAGATOSE & dTAG & - \\
\hline 35 & D-TREHALOSE & dTRE & + \\
\hline 36 & CITRATE(SODIUM) & CIT & + \\
\hline 37 & MALONATE & MNT & - \\
\hline 39 & 5-KETO-D-GLUCONATE & $5 \mathrm{KG}$ & - \\
\hline 40 & L-LACTATE alkalinisation & ILATk & + \\
\hline 41 & ALPHA-GLUCOSIDASE & AGLU & - \\
\hline 42 & SUCCINATE alkalinisation & SUCT & + \\
\hline 43 & Beta-N-ACETYL-GALACTOSAMINIDASE & NAGA & + \\
\hline 44 & ALPHA-GALACTOSIDASE & AGAL & - \\
\hline 45 & PHOSPHATASE & PHOS & + \\
\hline 46 & Glycine ARYLAMIDASE & GlyA & + \\
\hline 47 & ORNITHINE DECARBOXYLASE & ODC & + \\
\hline 48 & LYSINE DECARBOXYLASE & LDC & - \\
\hline 53 & L-HISTIDINE assimilation & IHISa & - \\
\hline 56 & COUMARATE & CMT & + \\
\hline 57 & BETA-GLUCORONIDASE & BGUR & - \\
\hline 58 & O/129 RESISTANCE (comp.vibrio.) & O129R & + \\
\hline 59 & Glu-Gly-Arg-ARYLAMIDASE & GGAA & - \\
\hline 61 & L-MALATE assimilation & IMLTa & - \\
\hline 62 & ELLMAN & ELLM & - \\
\hline 64 & L-LACTATE assimilation & ILATa & - \\
\hline
\end{tabular}


Table.5 Results of microbial identification using Biomerieux VITEK 2 system

\begin{tabular}{|c|c|c|c|}
\hline SL & & & \\
NO. & STRAIN REF. NO. & SPECIES IDENTIFIED & TEST METHOD \\
\hline 1 & TKMFT8,TKMFT22, & Staphylococcus sciuri & VITEK/GP CARDS \\
& TKMFT25,TKMFT39 & & \\
\hline 2 & TKMFT 53 & Achromobacter xylosoxidans & VITEK/GN CARDS \\
\hline
\end{tabular}

Fig.1 Zone of Diameter of protease producing bacterial isolates

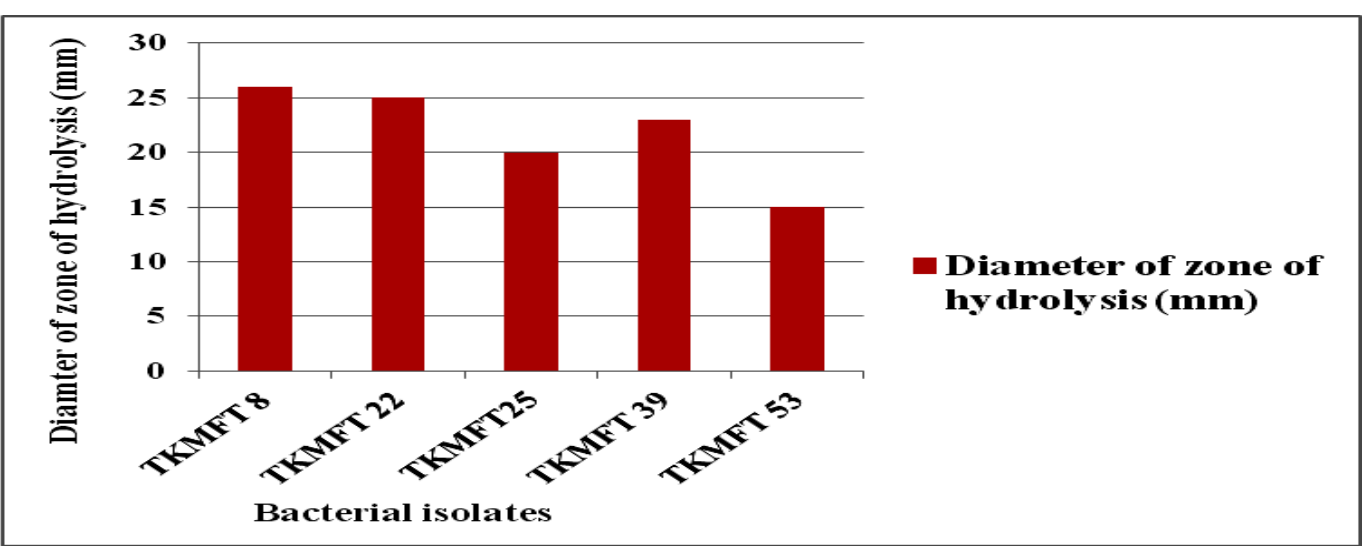

Photo.1 Isolated organisms on Nutrient Agar plates

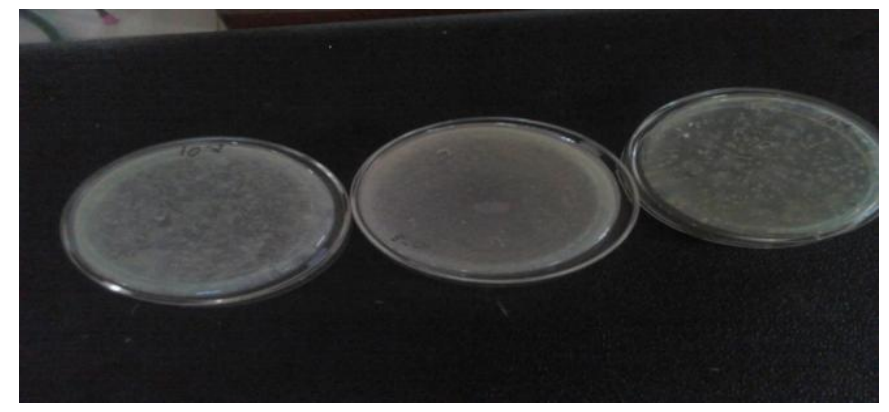

Photo.2 (a-e). Zone of hydrolysis on Gelatine agar

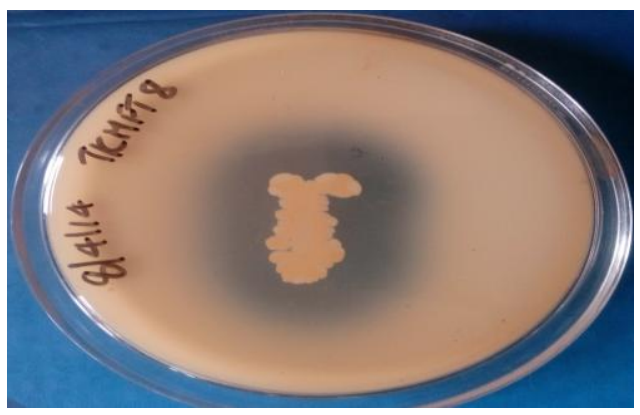

(a)

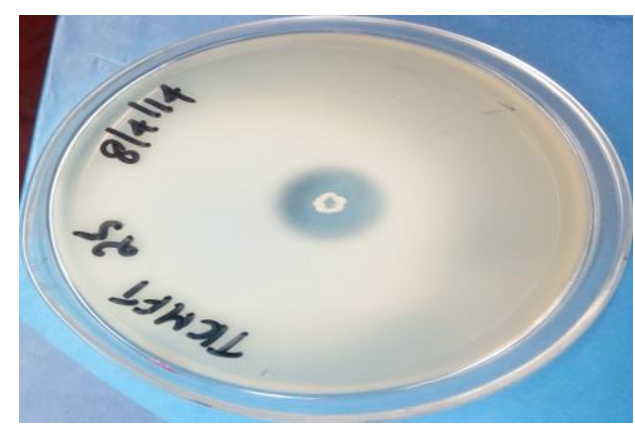

(b) 


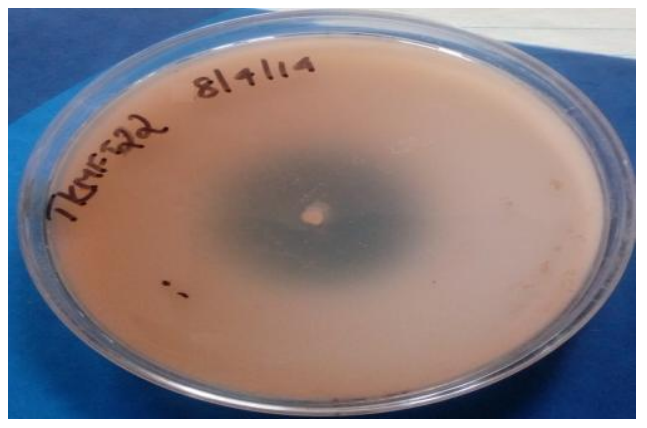

(c)

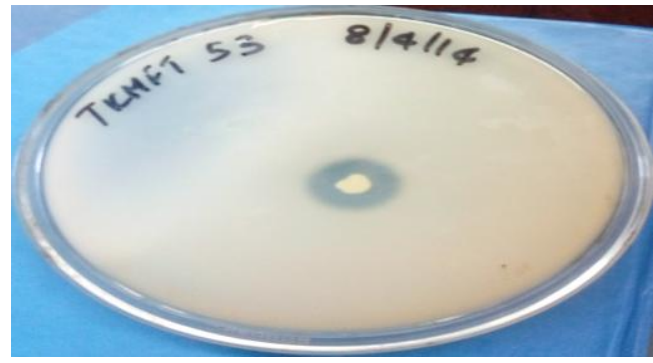

(e)

\section{Biochemical identification- Biomerieux VITEK 2 system}

The selected 5 isolates were identified using cultural characterization, microscopic observation and biochemical identification using Biomerieux VITEK 2 system. The results of cultural characterization and Microscopic observation were summarized in Table.2 and biochemical identification results using Biomerieux VITEK 2 system were presented in Table.3\& Table.4. Among the 5 isolates, TKMFT 8, 22, 25 and 39 are representing Staphylococcus sciuri and TKMFT 53 is representing Achromobacter xylosoxidans according to the test results. The results are presented in Table.5. Wallet et al., (2005) reported the performances of VITEK 2 Colorimetric Cards for Identification of Gram-Positive and Gram-Negative Bacteria. Earlier findings (Funke G et al., 1998) have proved the efficiency of VITEK -2 systems with $85.5 \%$ probability of accurate identification of strains. A similar study conducted by Simgamsetty et al., (2016) found to achieve 90-95\% probability of

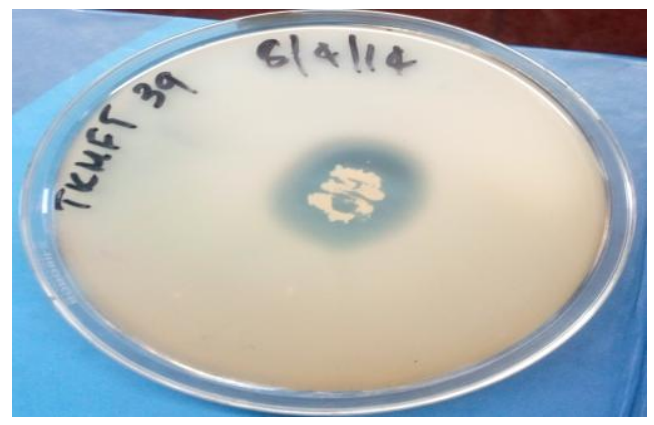

(d)

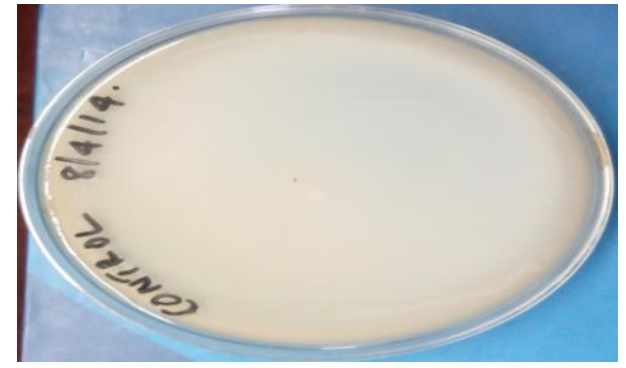

(f)

identification. In the present study, it was found to achieve $99 \%$ probability of identification for Staphylococcus sciuri (TKMFT8, TKMFT22, TKMFT25 \& TKMFT39) and $91 \%$ probability obtained for Achromobacter xylosoxidans (TKMFT53).

In conclusion, samples collected from food processing industries shows presence of potent protease producers. A total number of 5 isolates were selected based on zone diameter. All 5 isolates obtained by initial screening of protease production were identified based on cultural characteristics, microscopic observation and biochemical identification using Biomerieux VITEK 2 system, an automated microbiology system for identification of microorganisms. Among the 5 isolates, TKMFT $8,22,25 \& 39$ are representing Staphylococcus sciuri and TKMFT53 is representing Achromobacter xylosoxidans according to the test results. From the results it is inferred that the bacterial strain TKMFT8 produces maximal protease followed by TKMF22, TKMFT25, TKMFT39 and TKMFT53. 
Further these potent protease producers can be used for the degradation of proteinaceous waste from food processing industries. Hence the present study can play a significant role in the recycling of food industry wastes.

\section{Acknowledgement}

The author is very thankful to The Head, Cashew Export Promotion Council of India (CEPCI), Mundakkal, Kollam, and Kerala, India who has given the opportunity to carry out this work in the Microbiology department.

\section{References}

Ahmad, S.M. 2011. Productions of thermostable alkaline protease from an alkaline-resistant Streptomyces isolate EGS-5. Int. J. Acad. Res., 3: 393.

Anderson, J.K., Grimble, G.K. and Cowan, D.A. 1997. A process for producing a thermostable proteolytic enzyme from Thermoactinomyces thalpophilus THM1, PCT Patent Application, WO 23605.

Aneja, K.R. 2003. Experiments in Microbiology Plant Pathology and Biotechnology, $4^{\text {th }}$ edition. New Age International Publishers, New Delhi, India.

Barros, R.R., Carvalho, G.S., Peralta, J.M., Facklam, R.R. and Teixeira, L.M. 2001. Phenotypic and Genotypic Characterization of Pediococcus Strains Isolated from Human Clinical Sources. J. Clin. Microbiol., 39: 1241-1246.

Chang, Y.H., Han, J., Chun, J., Lee, K.C., Rhee, M.S., Kim, Y.B. and Bae, K.S.2002. Comamonas koreensis sp.nov., a non-motile species from wetland in Woopo, Korea. Int. J. Syst. Evol. Microbiol.,, 52: 377-318.

Coenye, T., Mahenthiralingam, E., Henry, D., Lipuma, J.J., Laevens, S., Gillis, M., Speert, D.P. and Vandamme, P.2001a.
Burkholderia ambifaria sp nov., a novel member of the Burkholderia cepacia complex including biocontrol and cystic fibrosis-related isolates. Int. J. Syst. Evol. Microbiol, 51, 1481-1490.

Collins, M.D., Hutson, R.A., Hoyles, L., Falsen, E., Nikolaitchouk, N. and Foster G.2001. Streptococcus ovis sp. nov. isolated from sheep. Int. J. Syst. Evol. Microbiol, 51, 1147-1150.

Collins, M.D. and Lawson, P.A.2000. The genus Abiotrophia (Kawamura et al.) is not monophiletic: proposal of Granulicatella gen. nov., Granulicatella adiacens comb.nov. Granulicatella elegans comb. nov.and Granulicatella balaenopterae comb. Nov. Int. J. Syst. Evol. Microbiol, 50, 365-369.

De Baere, T., Steyaert. Wauters, G., De Vos, P., Goris, J., Coenye, T., Suyama, T., Verschraegen, G. and Vaneechoutte, M.2001. Classification of Ralstonia pickettii biovar 3/ 'thomasii' strains (Pickett 1994) and of new isolates related to nosocomial recurrent meningitis as Ralstonia mannitolytica sp.nov. Int. J. Syst. Evol. Microbiol, 51: 547-558.

Deng, A., Wu, J., Zhang, Y., Zhang, G. and Wen, T. 2010. Purification and characterization of a surfactant-stable high alkaline protease from Bacillus sp. B001, Bioresour. Technol., 101, 71007116.

Funke, G., Monnet, D., deBernardis, C., von Graevenitz, A. and Freney, J.1998. Evaluation of the VITEK 2 system for rapid identification of medically relevant gram-negative rods. J. Clin. Microbiol., 36, 1948-1952.

Gessesse, A. and Gashe, B.A. 1997. Production of alka- line protease by an alkalophilic bacterium isolated from an alkaline soda lake. Biotechnol. Lett., 19, 479-481.

Grubb, J.D. 1994. Assay for bacterial type I 
collagenases. Methods Enzymol., 235, 602-606.

Heidari, H.R.K., Ziaee, A.A., Schaller, J. and Amoozegar, M.A.2007. Purification and characterization of an extra- cellular haloalkalineprotese produced by the moderately halophylic bacterium, Salinivibrio sp. strain AF-2004. Enzyme and Microbial Technol., 40, 266-272.

Lee, J.K., Kim, Y.O., Kim, H.K., Park, Y.S. and Oh, T.K.1996. Purification and characterization of a thermostable alkaline protease from Thermoactinomyces sp. E79 and the DNA sequence of the encoding gene. Biosci. Biotechnol. Biochem., 60, 840846.

Oyama, H., Kinjoh, M., Watari, M. and Murao, S.1997. Purification and characterization of an alkaline protease produced by Pimelobacter sp. Z-483. $J$. Fermentation and Bioengi., 84, 351353.

Poyart, C., Quesne, G. and Trieu-Cuot, P. 2002. Taxonomic dissection of the Streptococcus bovis group by analysis of manganese-dependent superoxide dismutase gene $(\operatorname{sod} A)$ sequences: reclassification of Streptococcus infantarius subsp. coli as Streptococcus lutetiensis sp.nov. and of Streptococcus bovis biotype II.2 as Streptococcus pasteurianus sp nov. Int. J. Syst. Evol. Microbiol., 52, 1247- 1255.

Rao, M.B., Tanksale, A.M., Ghatge, M.S. and Deshpande, V.V.1998. Molecular and biotechnological aspects of microbial proteases. Microbiol. Mol. Biol. Rev., 62, 597-635.

Rattray, F.P., Bockelmann, W. and Fox, P.F. 1995. Puri- fication and characterization of an extracellular proteinase from Brevibacterium linens ATCC 9174. Appl. Envi- ronmental Microbiol., 61, 3454-345.

Rifaat, H.M., Hassanein, S.M., El-Said, O.H.,
Saleh, S.M. and Selim, M.S.M. 2006. Purification and characterisa- tion of extracellular neutral protease from Streptomyces microflavus. Arab $J$. Biotechnol., 9, 51-60.

Rupali, D.2015. Screening and Isolation of Protease Producing Bacteria from Soil Collected from Different Areas of Burhanpur Region (MP) India. Int. J. Curr. Microbiol. App. Sci., 4,597-606.

Schlegel, L., Grimont, F., Collins, M.D., Regnault, B., Grimont, P.A.D. and Bouvet, A. 2000. Streptococcus infantarius sp. nov., Streptococcus infantarius subsp infantarius subsp. nov. and Streptococcus infantarius subsp coli subsp. nov.

Sjodahl, J., Emmer, A., Vincent, J. and Roeraade, J. 2002. Characterization of proteinases from Antarctic krill (Euphausia superba). Protein Expression and Purification, 26,153161.

Shafee, N., Aris, S.N., Rahman, R.N.Z.R.A. Basri, M. and Salleh, A.B. 2005. Optimization of environmental and nutritional conditions for the production of alkaline protease by newly isolated bacterium Bacillus cereus strain, $J$. Appl. Sci. Res, 1, 1-8.

Sharma, A.K., Sharma. Saxena, J., Yadav, B., Alam A. and Prakash, A.2015. Isolation and Screening of Extracellular Protease Enzyme from Bacterial and Fungal Isolates of Soil. Int. J. Scientific Res. Environ. Sci., 3, 334-340.

Shi, J., Coyne, V.E. and Weiner, R.M. 1997. Identification- tion of an alkaline metalloprotease produced by the hydrothermal vent bacterium Hyphomonas jannaschiana VP3. Microbios, 91, 1526.

Simgamsetty, S., Yarlagadda, P., Yenigalla, B.M. and Myneni, R.B. 2016. Ease with VITEK 2 systems, biomerieux in identification of non-lactose fermenting 
bacteria including their antibiotic drug susceptibility: our experience. Int. J. Res. Med. Sci., 4,813-817

Sinha, P., Singh, R.K., Srivastva, R., Sharma, R. and Tiwari, S.P. 2013. Characterization and optimization of alkaline protease enzyme produced by soil borne bacteria. Trends Life Sci., 2, 38-46.

Smith, S.K., Sutton, D.C., Fuerst, J.A. and Reichelt, J.L.1991. Evaluation of the Genus Listonella and the reassignment of Listonella damsela (Love et al.) MacDonell and Colwell to the Genus Photobacterium as Photobacterium damsela comb. nov. with an Emended Description. Int. J. Syst. Bacteriol., 41: 529-534.

Tennalli, G., Udapudi, B. and Naik, P. 2012. Isolation of Proteolytic Bacteria and Characterization of their Proteolytic Activity. Int. J. Adv. Engi. Sci. Technol., 2, 185-192.

Todar, K., Ubukata, M. and Hamada, M. 2005 .Microbiology of human Perspective. Mc Graw Hill Publisher, London

Valasaki, K., Staikou, A., Theodorou, L.G., Charamopou- lou, V., Zacharaki, P. and Papamichael, E.M.2008. Purification and kinetics of two novel thermophilic extracellular proteases from Lactobacillus helveticus, from kefir with possible biotechnological interest. Biores. Technol., 99, 5804-5813.

Vandamme, P., Goris, J., Coenye, T., Hoste, B., Janssens, D., Kersters, K., DeVos, P. and Falsen, E.1999. Assignment of Centers for Disease Control group IVc2 to the genus Ralstonia as Ralstonia paucula sp.nov. Int. J. Syst. Bacteriol., 49,663-669.

Wallet, F., Lor"ez, C., Renaux, E., Lemaitre. and Rene' J. Courcol,R.J.2005. Performances of VITEK 2 Colorimetric Cards for Identification of GramPositive and Gram-Negative Bacteria. $J$. Clin. Microbiol., 43, 4402-4406.

Whiley, R.A., Hall, L.M.C., Hardie, J.M. and Beighton, D. 1999. A study of small colony beta hemolytic, Lancefield group $\mathrm{C}$ streptococci within the anginosus group: description of Streptococcus constellatus subsp. pharynges subsp.nov. associated with the human throat and pharyngitis. Int. $J$. Syst. Bacteriol., 49, 1443-1449.

Yang, S.S. and Wang, J.Y. 1999. Protease and amylase production of Steptomyces rimosus in submerged and so- lid state cultivations. Botanical Bull. Academia Si- nica, 40, 259-265

Yeo, I.O., Choi, S.H., Lee, J.S. and Kim, C.J. 1995. Characteristics of an alkaline protease from Alteromonas sp. Agri. Chem. Biotechnol., 38, 106- 110.

\section{How to cite this article:}

Sony, I.S., and Potty, V.P. 2017. Biochemical Identification of Protease Producing Bacterial Isolates from Food Industries by Vitek 2 Compact System. Int.J.Curr.Microbiol.App.Sci. 6(2): 840-851. doi: http://dx.doi.org/10.20546/ijcmas.2017.602.094 